\title{
Evaluation of microalgae production coupled with wastewater treatment
}

De Francisci, Davide; Su, Yixi; lital, Arvo; Angelidaki, Irini

\section{Published in:}

Environmental Technology (United Kingdom)

Link to article, DOI:

$10.1080 / 09593330.2017 .1308441$

Publication date:

2018

Document Version

Peer reviewed version

Link back to DTU Orbit

Citation (APA):

De Francisci, D., Su, Y., lital, A., \& Angelidaki, I. (2018). Evaluation of microalgae production coupled with wastewater treatment. Environmental Technology (United Kingdom), 39(5), 581-592.

https://doi.org/10.1080/09593330.2017.1308441

\section{General rights}

Copyright and moral rights for the publications made accessible in the public portal are retained by the authors and/or other copyright owners and it is a condition of accessing publications that users recognise and abide by the legal requirements associated with these rights.

- Users may download and print one copy of any publication from the public portal for the purpose of private study or research.

- You may not further distribute the material or use it for any profit-making activity or commercial gain

- You may freely distribute the URL identifying the publication in the public portal

If you believe that this document breaches copyright please contact us providing details, and we will remove access to the work immediately and investigate your claim 


\section{Evaluation of microalgae production coupled with wastewater treatment}

\section{Davide De Francisci, Yixi Su, Arvo lital \& Irini Angelidaki}

To cite this article: Davide De Francisci, Yixi Su, Arvo lital \& Irini Angelidaki (2017): Evaluation of microalgae production coupled with wastewater treatment, Environmental Technology, DOI: 10.1080/09593330.2017.1308441

To link to this article: http://dx.doi.org/10.1080/09593330.2017.1308441

Accepted author version posted online: 17 Mar 2017.

Submit your article to this journal $\pi$

Џll Article views: 6

Q View related articles ¿

View Crossmark data $[\pi$ 
1 Publisher: Taylor \& Francis \& Informa UK Limited, trading as Taylor \& Francis

2 Group

3 Journal: Environmental Technology

4 DOI: $10.1080 / 09593330.2017 .1308441$

5

6 Evaluation of microalgae production coupled with wastewater

7 treatment

8 Davide De Francisci $^{\mathrm{a}}$, Yixi Su ${ }^{\mathrm{a}}$, Arvo Iital ${ }^{\mathrm{b}}$, Irini Angelidaki ${ }^{\mathrm{a}}$.

9 a. Technical University of Denmark, Department of Environmental Engineering,

10 Building 113, DK-2800 Kgs. Lyngby, Denmark.

11 b. Tallin University of Technology, Department of Environmental Engineering,

12 Ehitajate tee 5, 19086 Tallinn, Estonia.

13

14

15 Funding

16 This work resulted from the BONUS Microalgae project was supported by BONUS (Art 185),

17 funded jointly by the EU and the Danish Agency for Science, Technology and Innovation

18 (DASTI), the Estonian Environmental Investment Centre (KIK) and The Swedish Foundation 19 for Strategic Environmental Research (MISTRA).

20

\footnotetext{
${ }^{1}$ Corresponding author: Tel: +4545251680

E-mail address: dadf@env.dtu.dk (D. De Francisci)
} 


\author{
Davide De Francisci $^{\mathrm{a} 2}$, Yixi Su ${ }^{\mathrm{a}}$, Arvo Iital ${ }^{\mathrm{b}}$, Irini Angelidaki ${ }^{\mathrm{a}}$.
}

a. Technical University of Denmark, Department of Environmental Engineering, Building 113, DK-2800 Kgs. Lyngby, Denmark.

b. Tallin University of Technology, Department of Environmental Engineering, In the present study the feasibility of microalgae production coupled with wastewater treatment was assessed. Continuous cultivation of Chlorella sorokiniana with wastewater was tested in lab-scale flat panel photobioreactors. Biomass productivity was determined for four dilution rates $\left(4.32 \mathrm{~d}^{-1}, 3.6 \mathrm{~d}^{-1}, 1.8 \mathrm{~d}^{-1}\right.$ and $0.72 \mathrm{~d}^{-1}$ ). The productivity peak was $1.524 \mathrm{~g} \mathrm{l}^{-1} \mathrm{~d}^{-1}$ at the dilution rate of $2.41 \mathrm{~d}^{-1}$. Nitrogen and phosphorus removals were found to be inversely proportional to dilution rates, while COD removal was found to be $50 \%$ at all the tested conditions. The biomass obtained at the highest dilution rate was characterized for its content of lipids, proteins and pigments. The average yields of fatty acid methyl esters (FAME), protein, lutein, chlorophylls and $\beta$-carotene was $62.4 \mathrm{mg}, 388.2 \mathrm{mg}, 1.03$ $\mathrm{mg}, 11.82 \mathrm{mg}$ and $0.44 \mathrm{mg}$ per gram dry biomass, respectively. Economic analysis revealed that potentially more than $70 \%$ of revenue was from the production of pigments, i.e. chlorophyllin (59.6\%), lutein $(8.9 \%)$ and $\beta$-carotene $(5.0 \%)$ while reduction in discharging costs of the treated wastewaters could account for $19.6 \%$ of the revenue. Due to the low yield of FAME and the low market price of biodiesel, the revenue from the above was found to be the least profitable (1.4\%). Even when taking into account all these different revenues combined, this cultivation strategy was found with the current prices to be uneconomical. Power consumption for artificial light was responsible for the $94.5 \%$ of the production costs.

Keywords: Chlorella sorokiniana, biorefinery, wastewaters, photobioreactors, economic analysis

\footnotetext{
${ }^{2}$ Corresponding author: Tel: +4545251680

E-mail address: dadf@env.dtu.dk (D. De Francisci)
} 


\section{Introduction}

53 Increasing concerns about climate change and sustainability of fossil fuels based

54 economies have brought interest to microalgae for potential to establish bio-based economy, mainly due to their higher areal productivity over traditional biomasses [1].

56 Nevertheless, algal biomass production cost is still one major obstacle for 57 commercialization of algae-derived products, especially for the low-value ones such as biofuels. As a consequence, current application of algal biomass is centered on highvalue products (i.e. health, cosmetics, nutraceutical and food) [2]. In order to make the production of algal biomass profitable, efforts can be made on process integration, algal biology and cultivation system design [1, 3]. First, it is strongly recommended to produce biofuel simultaneously with value-added co-products, following a biorefinery strategy [4]. Furthermore, the combination of microalgae production with wastewater treatment for removal of nutrients and hazardous compounds can lead to a further step towards a cost-effective process, by saving the costs for $\mathrm{N}$ and $\mathrm{P}$ fertilizers when using nutrient rich streams [5, 6]. Moreover, revenue from wastewater treatment would help the overall process economy.

In this context, selection of appropriate algal species is pivotal: the ability of the species to grow in specific wastewaters and then generate biomass suitable for further transformation to high value products has a direct impact on the potential revenues.

71 Furthermore, the use of wastewater as the culturing media adds stricter requirements for 72 robustness of microalgae against adverse conditions, such as contamination with 73 possible toxic compounds and competition with undesired microorganisms [7, 8]. Zhou et al. [9] isolated multiple species from natural environments and screened five potential

75 high lipid producers in concentrated municipal wastewater by DNA sequencing: 76 Auxenochlorella protothecoides, Hindakia sp., Scenedesmus sp. and two Chlorella sp. 
77 A similar work found two Chlorella species, C. protothecoides and C. kessleri were microalgae species grown in wastewater, instead of widely used synthetic media for

100 the cultivation) into revenue deriving from the removal of the same nutrients as

101 environmental service. In this context, the algal biomass was used as a source for high 
102 added value products and biofuels to offset the production costs. Additionally, attempts

103 to improve the productivity via strain selection and optimization of cultivation-

104 operation were made. Based on the data generated, the economics of algal biomass

105 production was assessed in four scenarios considering an annual production of 330

106 days.

107

108 Materials and methods

109 Algal strains, medium and wastewater

110 Microalgal species Chlorella sorokiniana and Scenedesmus obliquus were chosen for

111 the initial screening because they are frequently found in different wastewaters [11-13]

112 and thus are expected to show robust growth in such environments. The strains were

113 obtained from SCAAP (Scandinavian Culture Collection of Algae \& Protozoa,

114 Denmark) and cultivated in sterilized Woods Hole medium (MWC) [18] containing

115 selenium.

116 Mixed influent industrial/municipal wastewater from Kohtla-Järve, Estonia was

117 selected for testing with algae based on the assumption that it represents typical

118 conditions in larger municipalities where industrial and municipal wastewaters as well

119 as storm water are mixed and then treated together. The mixed industrial/municipal

120 probe represented time-adjusted average water sample collected over 24 hours. The

121 water sample has been analysed by the Estonian Environment Research Centre and the 122 list of substances for the analyses involved $\mathrm{COD}_{\mathrm{Cr}}, \mathrm{TOC}, \mathrm{BOD}_{7}, \mathrm{NO}_{2}-\mathrm{N}, \mathrm{NO}_{3}-\mathrm{N}, \mathrm{NH}_{4}-$ $123 \mathrm{~N}, \mathrm{~N}_{\text {tot }}, \mathrm{PO}_{4}-\mathrm{P}$ and $\mathrm{P}_{\text {tot }}$. A number of hazardous compounds were present in the 124 wastewater and were analysed by Kohtla-Järve WWTP using standard procedures

125 (Table S1 in Supplementary Material). Part of the collected water sample was frozen ($12620^{\circ} \mathrm{C}$ ) and transported to Danish Technical University for further tests with microalgae. 
127 For all the cultivation experiments, wastewater underwent sedimentation to remove the

128 majority of solid particles. Sedimentation is considered an economic method in large

129 scale applications for gross separation of larger particles and therefore it was chosen as

130 separation methodology. Analysis of nutrients and organic compounds of the

131 supernatant after sedimentation was performed at the Technical University of Denmark.

132 Due to storage and sedimentation of the wastewater samples, some changes in

133 the water quality occurred, resulting in lower COD, $\mathrm{N}_{\text {tot }}$, and $\mathrm{P}_{\text {tot }}$ concentrations and

134 higher $\mathrm{NH}_{4}-\mathrm{N}$ content (Table 1).

\section{$136 \quad$ Microplate screening}

137 Screening for the best performing algal strain in the wastewater was carried out in 24-

138 well microplates (PE VISIPLATE, 24 well black-walled, clear bottomed). The

139 microplates were incubated at room temperature, illuminated by LED at $400 \pm 50 \mu \mathrm{mol}$

140 photons $\mathrm{m}^{-2} \mathrm{~s}^{-1}$ and shaken at $140 \mathrm{rpm}$ with a $50 \mathrm{~mm}$ throw. Growth was monitored by

141 fluorescence (440 nm emission, $690 \mathrm{~nm}$ detection) using a Synergy Mx microplate

142 reader (BioTek Instruments, Inc., USA).

143 Cultivation procedures, well-top membranes, growth rate calculations, and

144 detection limits were as described in recent study [19]. Each of the strains was

145 inoculated in triplicates in $100 \%$ wastewater or mixtures of wastewater and MWC + se

146 medium with varying percentages of wastewater $(75 \%, 50 \%$ and $25 \%)$. Culture volume 147 in each well was $2 \mathrm{ml}$. The screening was repeated for two generations for both species.

149 Photobioreactor cultivation

150 A flat-panel photobioreactor (Algaemist reactor, Wageningen University) was used to

151 cultivate $C$. sorokiniana with the wastewater pretreated by sedimentation. Undiluted 
152 wastewater was used for this set of cultivation experiments due to the positive results

153 obtained from the microplate screening where cultivation in undiluted wastewater

154 supported algal growth (see Results and discussion: Microplate screening).

155 The cultivation was initiated in batch mode. Parameter settings in this

156 experiment are listed in Table 2, and were chosen according to the optimal growth

157 condition for this species [20-22]. When the growth reached early stationary phase, the

158 cultivation was switched to continuous mode. The dilution rate was set to $4.32 \mathrm{~d}^{-1}$,

159 which was close to the maximum specific growth rate observed during the exponential

160 phase in batch mode. Thereafter, the dilution rate was stepwise decreased to $3.6 \mathrm{~d}^{-1}, 1.8$

$161 \mathrm{~d}^{-1}$ and $0.72 \mathrm{~d}^{-1}$. Optical density $\left(\mathrm{OD}_{750}\right)$ throughout the cultivation was monitored.

162 Moreover, biomass was collected for each dilution rate when the OD value was stable.

163 The temperature of the effluent was maintained at $4^{\circ} \mathrm{C}$ to inhibit algae metabolism and 164 growth after harvest.

165

\section{Analytical methods}

167 The samples obtained from the highest dilution rate was subject to lipid, protein and 168 pigment quantification.

170 Cell growth and dry cell weight

171 Cell growth of algae was monitored by measuring optical density at 680 and $750 \mathrm{~nm}$ 172 using a Hach Lange DR2800 spectrophotometer. The correlation between optical 173 density (OD) and dry weight (DW) concentration of samples $\left(C_{x}\right)$ was determined as 174 described in Van Wagenen et al. [17]. The correlation curve between $O D_{750}$ of cell

175 suspensions and dry weight of the biomass resulted to be linear, $C_{X}=0.31 O D_{750}-0.04$

176 with a $\mathrm{R}^{2}>0.95$ 
179 The procedure for the quantification of fatty acid methyl esters (FAMEs) was based on 180 the modified Folch method [23]. $10 \mathrm{mg}$ of freeze-dried and powdered biomass was 181 mixed to a solvent mixture of chloroform: methanol $(2 \mathrm{~mL}, 2: 1, \mathrm{v} / \mathrm{v})$ in duplicate. After 182 vortexing for 20 minutes, FAMEs were formed by addition $1 \mathrm{~mL}$ of methanol and 300 $183 \mu \mathrm{L}$ of $\mathrm{H}_{2} \mathrm{SO}_{4}$ and incubation at $100^{\circ} \mathrm{C}$ for 20 minutes. After cooling down, $1 \mathrm{~mL}$ of 184 distilled water was added to the sample, which was then vortexed for 5 minutes and 185 centrifuged at 4,000 rpm for 10 minutes. The lower layer including the organic solvent 186 was analysed with gas chromatography (HP 5890, Agilent, USA) with a flame ionized 187 detector (FID) and INNOWAX capillary column (Agilent, USA). The GC column 188 temperature was programmed as follows: (1) initial column temperature at $50{ }^{\circ} \mathrm{C}$, hold 189 for $1 \mathrm{~min},(2)$ increase to $200{ }^{\circ} \mathrm{C}$ at a rate of $15{ }^{\circ} \mathrm{C} \min ^{-1}$, hold for $9 \mathrm{~min}$, and (3)

190 increase to $250{ }^{\circ} \mathrm{C}$ at a rate of $2{ }^{\circ} \mathrm{C} \min ^{-1}$, maintain for $2 \mathrm{~min}$. Individual FAME

191 component was identified and quantified by comparing the retention times and peak 192 areas with those of the FAMEs standard solutions, respectively. The internal standard 193 was Supelco 37 Component FAME Mix, item no. 47885- U, Sigma-Aldrich.

195 Protein determination

196 For protein hydrolysis, duplicates of $50 \mathrm{mg}$ biomass were suspended in $6 \mathrm{ml}$ of $6 \mathrm{~N} \mathrm{HCl}$ 197 and transferred in close vessels. The vessels were flashed with nitrogen to prevent 198 oxidative degradation of some oxygen/sensitive amino acids. The vessels were then 199 microwaved for $30 \mathrm{~min}$ at 150 and 500W (Multiwave 3000, Anton Paar). Samples were 200 then freeze-dried to remove $\mathrm{HCl}$. The residues were resuspended in 400 milliQ $\mathrm{H}_{2} \mathrm{O}$ 201 and filtered through 0.22 syringe filters before the protein quantification by in-needle 
202 derivatization HPLC-FLD (Dionex UltiMate 3000, Thermo Scientific). Amino-acids 203 were separated in a c18 reversed phase column (Eclipse Plus C18, Agilent

204 Technologies, USA) with an in-line guard column (EC 4/2 Universal RP, Macherey205 Nagel, Germany) and mobile phases A (10mM Na $\left.2 \mathrm{HPO}_{4}, 10 \mathrm{mM} \mathrm{Na} \mathrm{B}_{4} \mathrm{O}_{7}\right)$ and $\mathrm{B}$ 206 (methanol: acetonitrile: water, 45:45:10). The flow rate was $0.420 \mathrm{~mL} \mathrm{~min}^{-1}$.

207 Quantitative analyses were performed by means of calibration curves using a 208 commercial amino-acid mix standard (AAS18 Fluka).

209

\section{Pigments determination}

211 Two milligrams of freeze-dried biomass were mixed with $3 \mathrm{ml}$ of $90 \%$ acetone in

212 duplicates. Well mixed samples were sonicated in ice bath for 10 min (Branson

213 3510MT). The supernatant was separated from the residual biomass by centrifugation at

214 13,000 rpm for $10 \mathrm{~min}$. A Zorbax Eclipse plus C8 RRHD $1.8 \mu \mathrm{m} 3.0 \times 150 \mathrm{~mm}$ column

215 was used for UHPLC separation at $60^{\circ} \mathrm{C}$ with a $75 \mathrm{~min}$ separation time. Detection

216 utilized UV-VIS at $450 \mathrm{~nm}$. Quantification was done relative to individual pigment

217 standards obtained from DHI, Hørsholm, diluted from 15 to $1500 \mu \mathrm{g} \mathrm{L}{ }^{-1}$.

218

219 Nutrient measurements

220 Samples corresponding to each dilution rates were centrifuged in order to harvest

221 biomass. The supernatants were collected for nutrient composition analysis. Contents of 222 COD, total nitrogen $\left(\mathrm{N}_{\mathrm{tot}}\right)$, total phosphorus $\left(\mathrm{P}_{\mathrm{tot}}\right)$ and ammonium were determined for 223 the supernatant using Hach Lange Cuvette Kits. (LCK314, LCK238 and LCK348, while 224 Spectroquant ${ }^{\circledR}$ ammonium test (Merck Millipore) was used for the measurement of 225 ammonium.

226 
228 Evaluation of economic potential of algae biomass was performed by calculating the 229 gross profit, taking into account only the difference between revenue and the operating 230 cost, without deducting costs for overhead, payroll, taxation and interest.

231 Specifically, a value of unit biomass was calculated as sum of revenues from all 232 products of interest, including biodiesel, proteins and pigments (e.g. lutein, chlorophylls 233 and $\beta$-carotene) as well as benefit for removing $\mathrm{COD}, \mathrm{N}$ and $\mathrm{P}$ from the wastewater. 234 Market value for each bioproduct obtained per unit biomass can be calculated from the 235 experimentally obtained yields, i.e. FAME $\left(C_{f}\right)$, amino acid $\left(C_{a a}\right)$ and pigments $\left(C_{p}\right)$. 236 Prices of desirable products (Table 3) were obtained from an e-commerce website: 237 www.alibaba.com. Specifications of the benchmark products can be found on the 238 company pages. The revenue from bio-products is the sum of production of each 239 product $\left(P_{i}\right)$ multiplied with its price, shown in the following equation.

$$
\text { Revenue }_{b}=\sum_{i} C_{i} \cdot \text { Price }_{i}
$$

240 Estimation of production cost was based on data from literature. Aim with this

241 preliminary economic assessment was to estimate which costs - revenues are more

242 important for the operational cost balance. The estimation only includes operation costs

243 and not initial investment costs. The rationale behind this was to generate a dataset that

244 could serve as a preliminary assessment of the profitability of this specific concept. In

245 case the process resulted to be not economically feasible based on operational costs and 246 revenues, it would be logical to assume investments for facilities construction would 247 make the economic prospects even more difficult. $\mathrm{CO}_{2}$ supply was the only input 248 needed cost, while nitrogen and phosphorus were considered free as present in the 249 wastewater. Power consumptions for light, $\mathrm{CO}_{2}$ sparging and harvesting were 250 considered main items of production cost for algal biomass. Additionally, cationic 
coagulant was chosen for the estimation of the harvesting costs due to its effectiveness and low cost compared to others [24]. Detailed calculation can be found in supplementary material.

\section{Scenarios for potential cost reduction}

256 A basic economic analysis was conducted to evaluate potential cost reduction

257 opportunities. In addition to the base case (where costs for $\mathrm{CO}_{2}$ and LED were both 258 taken into account), three alternative scenarios were proposed. Case (1) assumed 259 industrial flue gas containing $\mathrm{CO}_{2}$ was provided freely e.g. from a nearby power plant 260 without significant influence on cell growth and composition. In case (2), the cost for 261 power of lighting was eliminated by substituting artificial light with natural light source 262 (i.e. sunlight). Because of the unstable supply as a consequence of day-night cycle and seasonal variation, specific growth rate and cell density was assumed to decrease by

$26414 \%$ and $31 \%$, respectively [25]. In the third scenario, assumptions in case (1) and (2) 265 were combined.

\section{Statistics analysis}

268 IBM SPSS Statistics (Version 22) was used for statistical analysis. Data comparison

269 was performed using one way ANOVA test and unpaired t-test with 95\% confidential 270 intervals.

\section{Results and discussion}

\section{Microplate screening}

274 Based on specific growth rate (Figure 1), C. sorokiniana shows higher robustness in this

275 wastewater over S. obliquus at all conditions. The highest specific growth rates are 2.40 
$276 \mathrm{~d}^{-1}$ and $2.04 \mathrm{~d}^{-1}$ for $C$. sorokiniana and S. obliquus, respectively, which are obtained in a

277 mixture with $50 \%$ wastewater in the second generation. Acclimation in the second

278 generation was observed for both species. Furthermore, when wastewater concentration

279 was higher than $50 \%$, growth rates were inversely proportional to wastewater

280 concentration for both species, which suggests possible inhibitory effects of wastewater

281 on the algal growth.

282 This could be due to presence of hazardous compounds from the oil-shale

283 industry in the KJ wastewater, which can potentially be harmful to microalgae species.

284 At the same time, undiluted wastewater contains the highest concentration of nutrients

285 and therefore leads to the highest cell density of $C$. sorokiniana (Figure 2), even with a

286 lower growth rate. The same tendency was observed in a previous study, where $100 \%$

287 wastewater resulted in initial inhibition to algae, but eventually it resulted in the highest

288 algae density compared to diluted concentrate [26]. Based on these results and on

289 considerations that dilution of wastewater would be more technical complex and costly,

290 undiluted wastewater was used for the photobioreactor (PBR) experiments.

292 Algae productivity

293 Average biomass productivities and biomass concentration measured at steady states of

294 four dilution rates are shown in Figure 3. The cultivation was initiated with the dilution

295 rate $\left(4.32 \mathrm{~d}^{-1}\right)$ close to the maximal specific growth rate $\left(4.56 \mathrm{~d}^{-1}\right)$ observed in a batch 296 cultivation in the same wastewater. This dilution rate led to the lowest biomass 297 concentration $\left(0.18 \mathrm{~g} \mathrm{l}^{-1}\right)$ and, as a consequence, to the lowest productivity $\left(0.8 \mathrm{~g} \mathrm{l}^{-1} \mathrm{~d}^{-1}\right)$.

298 With the decrease of dilution rates, biomass concentration rose to $1.44 \mathrm{~g} \mathrm{l}^{-1}$, (dilution 299 rate of $\left.0.72 \mathrm{~d}^{-1}\right)$ corresponding to low productivity $\left(0.95 \mathrm{~g} \mathrm{l}^{-1} \mathrm{~d}^{-1}\right)$. The highest biomass 300 productivity $\left(1.46 \mathrm{~g} \mathrm{l}^{-1} \mathrm{~d}^{-1}\right)$ was exhibited at a dilution rate of $1.8 \mathrm{~d}^{-1}$. The curve 
describing the correlation between dilution rate and biomass productivity was fitted to a

302 binomial equation, and the highest productivity was estimated to be $1.524 \mathrm{~g}^{-1} \mathrm{~d}^{-1}$ at a 303 dilution rate of $2.41 \mathrm{~d}^{-1}$, corresponding to a cell density of $0.63 \mathrm{~g} \mathrm{l}^{-1}$.

304 The trend seen with decrease of cell concentration with increasing dilution rates 305 is contradictory to the theoretical expected. The expected trend would be that the cell 306 concentration was stable with increasing dilution rate, until initiation of wash out which

307 would correspond to a sharp decrease the cell concentration.

308 The explanation to the observed relationship could be due to the spontaneous

309 flocculation and wall attachment occurred during the cultivation (Figure 4). The

310 calibration curve (section Analytical methods) used to calculate cell concentration was

311 generated using homogeneously suspended cells, and therefore OD measurements do

312 not reflect cell concentrations of flocculant cell associations. High flow rates (high

313 dilution rates) in upflow reactor systems are causing selection pressure to the cells. Only

314 cells managing to create flocs are resisting wash out, by creating flocs presenting larger

315 diameter than the single cells and thereby having a higher sedimentation rate, while the

316 suspended cells are washed out of the reactor. Therefore high dilution rates are

317 promoting flocculation and thereby OD measurements at these high rates are giving an

318 underestimation of the cell concentration.

319 Previous studies employed the same photobioreactor system (flat plate) used in 320 the current one $[16,17]$ and have found similar trends. The operation conditions and 321 growth data achieved in these previous publications listed in Table 4 for comparison. In 322 Van Wagenen et al. [17] parallel experiments were conducted with a high light intensity $323\left(2100 \mu \mathrm{mol} \mathrm{m} \mathrm{m}^{-2} \mathrm{~s}^{-1}\right)$ and a low light intensity $\left(200 \mu \mathrm{mol} \mathrm{m} \mathrm{m}^{-2} \mathrm{~s}^{-1}\right)$. The operating 324 conditions of the present study (wastewater instead of synthetic media and low light 325 intensity) are very similar. 
327 low light experiment in Van Wagenen et al. [17], lower biomass density and 328 productivity were obtained. A reason for this difference could be the different nutrient 329 supplements in the media used. The nutrient content, especially nitrogen in Kohtla-Järve 330 influent wastewater was considerably lower compared to the aforementioned study 331 (Table 5). It has been proven that biomass concentration and $\mathrm{NO}_{3}-\mathrm{N}$ supply are 332 positively correlated, up to a saturation level of about $30 \mathrm{mg} \mathrm{NO}_{3}-\mathrm{N} \mathrm{l}^{-1}$ (further increase 333 of cell density was limited, which may be caused by the limitation of other nutrients)

334 [27]. The positive effect of increasing nitrogen and phosphorus concentration on algal 335 growth was also reported, demonstrating that the highest level of algal biomass 336 corresponded to the highest initial $\mathrm{N}_{\text {tot }}$ of $25 \mathrm{mg} \mathrm{l}^{-1}$ [28].

\section{$338 \quad$ Nutrient removal}

339 Nitrogen and phosphorus concentrations were determined for the treated wastewater 340 and for the resulting biomass after harvesting. Nutrient contents of the treated 341 wastewater were compared with the composition of untreated wastewater.

342 Removal efficiencies at different dilution rates are shown in Figure 5. Overall, 343 the highest removal efficiencies $(>90 \%)$ were observed at the lowest dilution rate $(0.72$

$\left.344 \mathrm{~d}^{-1}\right)$. With the decrease of dilution rate, the removals of total nitrogen, total phosphorus 345 and ammonium were steadily increased. However, the removal of COD for all dilution 346 rates remained around 50\%. Limited COD reduction was also previously reported [29, 34730 ]. This indicates that the residual $\sim 50 \%$ of COD consisted by organics not degradable 348 by microalgae. This also shows that organic carbons were consumed very quickly in

349 these experiments and therefore were the preferred carbon source by $C$. sorokiniana 350 over $\mathrm{CO}_{2}$ (heterotrophy/mixotrophy). This is in agreement with a previous study, in 
351 which batch cultivations of $C$. sorokiniana were conducted at increasing concentration 352 of organic carbon, with the highest growth rate corresponding to the highest 353 concentration [31].

354 Van Wagenen et al. [17] observed very high removal efficiencies for $\mathrm{PO}_{4}-\mathrm{P}$ in 355 all the tested dilution rates. In the present work phosphorus removal rate was instead 356 increased with dilution rate. An explanation for this could be the fact that phosphorus 357 was in excess in the wastewater used in this previous study $(\mathrm{N} / \mathrm{P}$ ratio was $36.5: 1$ in Van 358 Wagenen et al. [17] while it was only 14.9:1 in the Kohtla-Järve influent wastewater 359 which we used in this study).

360 Finally, average concentrations of mineral elements present in the algal biomass

361 are $8.87 \% \mathrm{~N}$ and $1.04 \% \mathrm{P}$, which partly represent the nutrients transferred from 362 wastewater to biomass. Similar N and P contents were also reported when microalgae were grown in dairy manure and obtained biomass consisting of $7 \% \mathrm{~N}$ and $1 \% \mathrm{P}$ [32].

\section{Biomass characterization}

366 Compositional analysis of the algal biomass grown in wastewater is listed in Table 6.

367 Palmitic acid (16:0), palmitoleic acid (16:1), oleic acid (18:1) and linolenic acid (18:3)

368 were found to be the most abundant fatty acids present in the algal biomass (Table 7).

369 This is in agreement with typical fatty acid composition of $C$. sorokiniana found in 370 literature [33-36].

371 Fatty acid content in C. sorokiniana can vary from $0.6 \%$ to $47.51 \%$ depending 372 mainly on the growth conditions (Table 8). FAME yield of current study is relatively 373 low compared to fatty acid contents of $C$. sorokiniana reported in literature.Nitrogen 374 starvation has been widely recognized as a stress condition which stimulates the 375 accumulation of lipids. Li et al. [46] showed that the initial nitrogen concentration in the 
376 medium was positively correlated with the growth of $C$. sorokiniana, but reversely

377 correlated with the lipid content. Lipid accumulation is believed to be a consequence of

378 the inhibition of proteins and starch biosynthesis which usually occurs in stationary

379 phase

380 Furthermore, composition of the lipid profile is in general correlated to culturing

381 conditions, and this may be another reason for low fatty acid content in the algal

382 biomass produced in the present work. In contrast to polar lipids (e.g. membrane

383 components), neutral lipids are responsible for energy storage in cells and are precursors

384 for FAME production. It has been shown that different nutritional conditions can affect

385 the percentage of neutral lipids within the total lipid content varying from $2.9 \%$ to $60 \%$

386 [36]. In addition, low irradiation, as in the present study, induces the formation of polar

387 lipids, whereas the formation of triacylglycerols is favoured at high light intensity

388 conditions [48]. Also, although results show that available organic carbon source was

389 consumed, nitrogen and phosphorus were still abundant in the effluent of culture

390 (Figure 5). Therefore, microalgae in this condition were not stressed by nutrient

391 limitation and thus tended to invest carbon and energy for cell growth. The high protein

392 content $38.82 \%(\mathrm{w} / \mathrm{w})$ in the algal biomass is an indicator for the active proliferation. In

393 conclusion, in the present work the high growth rate (supported by sufficient nutrient

394 supplement) was probably the reason for the relatively low fatty acid yield. Clearly,

395 there is a tradeoff between biomass productivity and lipid content that cannot be 396 achieved simultaneously. This is why two-phase cultivation strategies are a possible 397 solution for the economics of algae cultivation $[49,50]$.

399 Estimation of biomass value and economic potential 
400 The revenue generated from cultivationg $C$. sorokiniana in this specific wastewater is 401 estimated to be $3.27 € \mathrm{~kg}^{-1}$ dry biomass, which includes $2.63 € \mathrm{~kg}^{-1}$ (80.4\%) from the 402 production of valuable bioproducts and $0.64 € \mathrm{~kg}^{-1}(19.6 \%)$ from removal of nutrients 403 from wastewater as an environmental service (Table 9).

404 More specifically, chlorophyllin accounts for $59.7 \%$ of the total value, whereas 405 the share of biodiesel is negligible (1.4\%) as a consequence of the low FAME yield. As 406 per kilo of microalgae produced, roughly $1580 \mathrm{~L}$ wastewater can be treated at a dilution 407 rate of $2.41 \mathrm{~d}^{-1}$, which makes significant contribution $(19.6 \%)$ to the overall revenue. 408 However, the nutrient removal efficiencies in this condition are unsatisfactory for 409 treating wastewater. Removal efficiencies of only $52.1 \%$ for COD, $57.5 \%$ for nitrogen 410 and $68.8 \%$ for phosphorus were achieved. The cost for producing a kilo of microalgae 411 was estimated to be $12.46 € \mathrm{~kg}^{-1}$ comprising $94.5 \%$ for power for illumination, whereas 412 the remaining $5.5 \%$ was for $\mathrm{CO}_{2}$ supply $(2.7 \%)$, cost of cationic flocculant $(0.4 \%)$, 413 power for harvest $(2.1 \%)$ and aeration $(0.3 \%)$.

414 As already mentioned, biodiesel is the least remunerative product. Despite the 415 fast growth of $C$. sorokiniana, the parallel low FAME production largely affects the 416 economics of the strategy presented in this study. Furthermore, coupling biomass 417 production and wastewater treatment contributes to the total revenue. However, the $418 \mathrm{COD}$ and nutrients removal efficiencies at the dilution rate, $2.41 \mathrm{~d}^{-1}$ were poor. 419 Consequently, the resulted wastewater may not fulfill the quality for reuse and may 420 require additional steps for further treatment.

421 Finally, the economic potential in the case of utilizing artificial light is $-9.19 €$ $422 \mathrm{~kg}^{-1}$-biomass, showing economically unsustainable production. 
425 Economics of algal biomass production was assessed in four scenarios considering an 426 annual production of 330 days. The results indicate the economic potential can be 427 positive only when the cost for artificial light is eliminated (Figure 6). Results show that 428 the substitution of artificial light with sunlight can reduce production cost by $96.0 \%$, 429 whereas the reduction resulted from using free $\mathrm{CO}_{2}$ is $2.7 \%$. The elimination of $\mathrm{CO}_{2}$ 430 cost has relatively little effect $(+3.6 \%)$ on the overall cost reductions. By contrast, 431 economical potential can be increased by $116.1 \%$ and become positive as a result of 432 considerable drop in cost for artificial light.

433 On the other hand, the substitution of artificial light by sunlight hypothetically 434 causes $14 \%$ and $31 \%$ reduction in specific growth rate and cell density, respectively 435 [25], resulting in $40.7 \%$ reduction in biomass productivity. As a consequence, annual 436 revenue is reduced by $39.6 \%$. In addition, because nitrogen removal is $56 \%$ less in a 437 light-dark cycle condition in comparison with continuous illumination [51], the shorter 438 illumination period leads to further decrease in nitrogen removal efficiency to $26.8 \%$.

439 This analysis highlights that excluding use of artificial light is an imperative to 440 enable sustainable production of algal biomass for any purpose. In the base case, at least $44176.5 \%$ of the cost for artificial light needs to be reduced to ensure breakeven for the 442 necessary utilities for biomass production (e.g. electricity, flocculant and $\mathrm{CO}_{2}$ ). In the 443 case that excludes the costs for $\mathrm{CO}_{2}$ and light, biomass cost is reduced to $424 € \mathrm{t}^{-1}$, 444 which is substantially lower than $5,960 € \mathrm{t}^{-1}$ as reported in [52] and 2,340 $\$ \mathrm{t}^{-1}$ reported 445 in [53]. Exclusion of capital cost and operational cost such as labour and general plant 446 overhead is one major reason for the underestimation in our estimation. Furthermore, 447 some basic assumptions for the calculation are different. For example, aeration power 448 accounted for the biggest fraction of cost in Norsker et al.'s calculation, which is 449 relatively low in the present work. 


\section{Conclusion}

453 This work demonstrated that microalga $C$. sorokiniana can well adapt to the wastewater

454 chosen for this assessment and thus exhibits high biomass productivity. The cultivation

455 led to a significant but not optimal removal of COD, N and P. Nitrogen and phosphorus

456 removals were observed to be inversely proportional to dilution rates, while COD

457 removal was found to be constant. Microalgae cultivation can therefore be considered a

458 promising tool for partial nutrient recovery from wastewaters, but not yet an ideal tool

459 to meet wastewater treatment plants requirements. In this context, the nutrient recovery

460 translates in the production of valuable biomass that could make the entire process

461 profitable. The composition of the resulting biomass was determined in respect to lipids,

462 proteins and pigments content. The economic assessment performed on the entire

463 process showed that pigments in particular could play a pivotal role in economics of

464 algae production and should be the primary goal to pursue. It is noteworthy that the

465 cultivation conditions in the present study were generally chosen to ensure optimal

466 microalgae growth and optimal biomass productivity. However, the same conditions

467 translate in poor content of high value products in the same biomass. For this reason it

468 is advisable to develop two-phase cultivation strategies, in which microalgae are first

469 kept in optimal growth conditions to generate high biomass yield, and then stressed to 470 increase the high added value products content in the same biomass.

471 Finally the economic assessment performed on this specific species/wastewater 472 combination proved this cultivation strategy to be uneconomical, mostly due to the 473 energy consumption for artificial light, which accounts for $94.5 \%$ of the production 474 costs. 


\section{References}

481

482

483

484

485

486

487

488

489

490

491

492

493

494

495

496

497

498

499

500

501

502

503

504

505

506

507

508

509

510

511

512

513

[1] Chisti Y. Biodiesel from microalgae. Biotechnology Advances. 2007;25(3):294-306.

[2] Foley PM, Beach ES, Zimmerman JB. Algae as a source of renewable chemicals: opportunities and challenges. Green Chemistry. 2011;13(6):1399-405.

[3] Acién F, Fernández J, Magán J, et al. Production cost of a real microalgae production plant and strategies to reduce it. Biotechnology Advances. 2012;30(6):1344-53.

[4] Rawat I, Bhola V, Kumar RR, et al. Improving the feasibility of producing biofuels from microalgae using wastewater. Environmental Technology.2013;34(1314):1765-75.

[5] Abdelaziz AE, Leite GB, Hallenbeck PC. Addressing the challenges for sustainable production of algal biofuels: I. Algal strains and nutrient supply. Environmental Technology. 2013;34(13-14):1783-805.

[6] Christenson L, Sims R. Production and harvesting of microalgae for wastewater treatment, biofuels, and bioproducts. Biotechnology Advances. 2011;29(6):686-702.

[7] Cho S, Luong TT, Lee D, et al. Reuse of effluent water from a municipal wastewater treatment plant in microalgae cultivation for biofuel production. Bioresource Technology. 2011;102(18):8639-45.

[8] Osundeko O, Dean AP, Davies H, et al. Acclimation of microalgae to wastewater environments involves increased oxidative stress tolerance activity. Plant and Cell Physiology. 2014;55(10):1848-57.

[9] Zhou W, Li Y, Min M, et al. Local bioprospecting for high-lipid producing microalgal strains to be grown on concentrated municipal wastewater for biofuel production. Bioresource Technology. 2011;102(13):6909-19.

[10] Li Y, Zhou W, Hu B, et al. Integration of algae cultivation as biodiesel production feedstock with municipal wastewater treatment: strains screening and significance evaluation of environmental factors. Bioresource Technology. 2011;102(23):108617.

[11] de Godos I, Vargas VA, Blanco S, et al. A comparative evaluation of microalgae for the degradation of piggery wastewater under photosynthetic oxygenation.

Bioresource Technology. 2010;101(14):5150-8.

[12] Mustafa E-M, Phang S-M, Chu W-L. Use of an algal consortium of five algae in the treatment of landfill leachate using the high-rate algal pond system. Journal of Applied Phycology. 2012;24(4):953-63.

[13] Samorì G, Samorì C, Guerrini F, et al. Growth and nitrogen removal capacity of Desmodesmus communis and of a natural microalgae consortium in a batch culture system in view of urban wastewater treatment: Part I. Water Research. 2013;47(2):791-801.

[14] Larsdotter K. Wastewater treatment with microalgae-a literature review. Vatten. 2006;62(1):31.

[15] Fernandez F, Camacho FG, Perez J, et al. Modeling of biomass productivity in tubular photobioreactors for microalgal cultures: effects of dilution rate, tube 

16.

[16] Cuaresma M, Janssen M, Vílchez C, et al. Productivity of Chlorella sorokiniana in a short light- path (SLP) panel photobioreactor under high irradiance. Biotechnology and Bioengineering. 2009;104(2):352-9.

[17] Van Wagenen J, Pape ML, Angelidaki I. Characterization of nutrient removal and microalgal biomass production on an industrial waste-stream by application of the deceleration-stat technique. Water Research. 2015;75:301-11.

[18] Guillard RR. Culture of marine invertebrate animals: culture of phytoplankton for feeding marine invertebrates. New York (NY): Springer; 1975.

[19] Van Wagenen J, Holdt SL, De Francisci D, et al. Microplate-based method for high-throughput screening of microalgae growth potential. Bioresource Technology. 2014;169:566-72.

[20] Li T, Zheng Y, Yu L, et al. High productivity cultivation of a heat-resistant microalga Chlorella sorokiniana for biofuel production. Bioresource Technology. 2013;131:60-7.

[21] Yoshida N, Ikeda R, Okuno T. Identification and characterization of heavy metalresistant unicellular alga isolated from soil and its potential for phytoremediation. Bioresource Technology. 2006;97(15):1843-9.

[22] Zheng Y, Chi Z, Lucker B, et al. Two-stage heterotrophic and phototrophic culture strategy for algal biomass and lipid production. Bioresource Technology. 2012;103(1):484-8.

[23] Folch J, Lees M, Sloane-Stanley G. A simple method for the isolation and purification of total lipids from animal tissues. J Biol Chem. 1957;226(1):497-509.

[24] Udom I, Zaribaf BH, Halfhide T, et al. Harvesting microalgae grown on wastewater. Bioresource Technology. 2013;139:101-6.

[25] Wang S-K, Hu Y-R, Wang F, et al. Scale-up cultivation of Chlorella ellipsoidea from indoor to outdoor in bubble column bioreactors. Bioresource Technology. 2014; 156:117-22.

[26]. Kong Q-X, Li L, Martinez B, et al. Culture of microalgae Chlamydomonas reinhardtii in wastewater for biomass feedstock production. Applied Biochemistry and Biotechnology. 2010;160(1):9-18.

[27] Mostert ES, Grobbelaar U. The influence of nitrogen and phosphorus on algal growth and quality in outdoor mass algal cultures. Biomass. 1987;13(4):219-33.

[28] Xin L, Hong-ying H, Ke G, et al. Effects of different nitrogen and phosphorus concentrations on the growth, nutrient uptake, and lipid accumulation of a freshwater microalga Scenedesmus sp. Bioresource Technology. 2010;101(14):5494-500.

[29]. Min M, Wang L, Li Y, et al. Cultivating Chlorella sp. in a pilot-scale photobioreactor using centrate wastewater for microalgae biomass production and wastewater nutrient removal. Applied Biochemistry and Biotechnology. 2011;165(1):123-37.

[30] Ruiz J, Álvarez-Díaz P, Arbib Z, et al. Performance of a flat panel reactor in the continuous culture of microalgae in urban wastewater: prediction from a batch experiment. Bioresource Technology. 2013;127:456-63.

[31] Kim S, Park J-e, Cho Y-B, et al. Growth rate, organic carbon and nutrient removal rates of Chlorella sorokiniana in autotrophic, heterotrophic and mixotrophic conditions. Bioresource Technology. 2013;144:8-13.

[32] Mulbry W, Kondrad S, Pizarro C,et al. Treatment of dairy manure effluent using freshwater algae: algal productivity and recovery of manure nutrients using pilotscale algal turf scrubbers. Bioresource Technology. 2008;99(17):8137-42. 
600

601

602

603

604

605

606

607

608

609

610

611

612

613

614

615

616

617

618

619

620

[33] Chen F, Johns MR. Effect of $\mathrm{C} / \mathrm{N}$ ratio and aeration on the fatty acid composition of heterotrophicChlorella sorokiniana. Journal of Applied Phycology. 1991;3(3):2039.

[34] Li T, Zheng Y, Yu L, et al. Mixotrophic cultivation of a Chlorella sorokiniana strain for enhanced biomass and lipid production. Biomass and Bioenergy. 2014;66:204-13.

[35] Patterson GW. Effect of culture temperature on fatty acid composition ofChlorella sorokiniana. Lipids. 1970;5(7):597-600.

[36] Wan MX, Wang RM, Xia JL, Rosenberg JN, Nie ZY, Kobayashi N, et al. Physiological evaluation of a new Chlorella sorokiniana isolate for its biomass production and lipid accumulation in photoautotrophic and heterotrophic cultures. Biotechnology and Bioengineering. 2012;109(8):1958-64.

[37] Matsukawa R, Hotta M, Masuda Y, et al. Antioxidants from carbon dioxide fixing Chlorella sorokiniana. Journal of Applied Phycology. 2000;12(3-5):263-7.

[38] Hunt RW, Chinnasamy S, Bhatnagar A, et al. Effect of biochemical stimulants on biomass productivity and metabolite content of the microalga, Chlorella sorokiniana. Applied Biochemistry and Biotechnology. 2010;162(8):2400-14.

[39] Wan M, Liu P, Xia J, et al. The effect of mixotrophy on microalgal growth, lipid content, and expression levels of three pathway genes in Chlorella sorokiniana. Applied Microbiology and Biotechnology. 2011;91(3):835-44.

[40] Lu S, Wang J, Niu Y, et al. Metabolic profiling reveals growth related FAME productivity and quality of Chlorella sorokiniana with different inoculum sizes. Biotechnology and Bioengineering. 2012;109(7):1651-62.

[41] Chen C-Y, Chang J-S, Chang H-Y, et al. Enhancing microalgal oil/lipid production from Chlorella sorokiniana CY1 using deep-sea water supplemented cultivation medium. Biochemical Engineering Journal. 2013;77:74-81.

[42] Kobayashi N, Noel EA, Barnes A, et al. Characterization of three Chlorella sorokiniana strains in anaerobic digested effluent from cattle manure. Bioresource Technology. 2013;150:377-86.

[43] Zheng Y, Li T, Yu X, et al. High-density fed-batch culture of a thermotolerant microalga Chlorella sorokiniana for biofuel production. Applied Energy. 2013;108:281-7.

[44] Ramanna L, Guldhe A, Rawat I, et al. The optimization of biomass and lipid yields of Chlorella sorokiniana when using wastewater supplemented with different nitrogen sources. Bioresource Technology. 2014;168:127-35.

[45] Juntila D, Bautista M, Monotilla W. Biomass and lipid production of a local isolate Chlorella sorokiniana under mixotrophic growth conditions. Bioresource Technology. 2015;191:395-8.

[46] Li YX, Zhao FJ, Yu DD. Effect of nitrogen limitation on cell growth, lipid accumulation and gene expression in Chlorella sorokiniana. Brazilian Archives of Biology and Technology. 2015;58(3):462-7.

[47] Deng X, Fei X, Li Y. The effects of nutritional restriction on neutral lipid accumulation in Chlamydomonas and Chlorella. African Journal of Microbiology Research. 2011;5(3):260-70.

[48] Khotimchenko SV, Yakovleva IM. Lipid composition of the red alga Tichocarpus crinitus exposed to different levels of photon irradiance. Phytochemistry. 2005;66(1):73-9.

[49] Samorì G, Samorì C, Pistocchi R. Nutrient removal efficiency and physiological responses of Desmodesmus communis at different HRTs and nutrient stress 
621

622

623

624

625

626

627

628

629

630

631

632

633

634

635

636

637

638

639

640

641

642

643

644

645

646

647

648

649

650

651

652

653

654

655

656

657

658

condition using different sources of urban wastewater effluents. Applied Biochemistry and Biotechnology. 2014;173(1):74-89.

[50] Su C-H, Chien L-J, Gomes J, et al. Factors affecting lipid accumulation by Nannochloropsis oculata in a two-stage cultivation process. Journal of Applied Phycology. 2011;23(5):903-8.

[51] Lee K, Lee C-G. Effect of light/dark cycles on wastewater treatments by microalgae. Biotechnology and Bioprocess Engineering. 2001;6(3):194-9.

[52] Norsker N-H, Barbosa MJ, Vermuë MH, et al. Microalgal production-a close look at the economics. Biotechnology Advances. 2011;29(1):24-7.

[53] Chauton MS, Reitan KI, Norsker NH, et al. A techno-economic analysis of industrial production of marine microalgae as a source of EPA and DHA-rich raw material for aquafeed: Research challenges and possibilities. Aquaculture. 2015;436:95-103.

(1)

(1)

(1)


660 Table 1 Composition of KJ wastewater.

\begin{tabular}{lll}
\hline Indicator & Before sedimentation & After sedimentation \\
\hline COD & $442 \mathrm{mg} \mathrm{O}_{2} \mathrm{l}^{-1}$ & $386.9 \mathrm{mg} \mathrm{O}_{2} \mathrm{l}^{-1}$ \\
$\mathrm{~N}_{\text {tot }}$ & $117 \mathrm{mg} \mathrm{N}^{-1}$ & $48.6 \mathrm{mg} \mathrm{N}^{-1}$ \\
$\mathrm{P}_{\text {tot }}$ & $10.5 \mathrm{mg} \mathrm{P} \mathrm{l}^{-1}$ & $7.2 \mathrm{mg} \mathrm{P} \mathrm{l}^{-1}$ \\
$\mathrm{NH}_{4}-\mathrm{N}$ & $34.7 \mathrm{mg} \mathrm{N} \mathrm{l}^{-1}$ & $46.7 \mathrm{mg} \mathrm{N} \mathrm{l}^{-1}$
\end{tabular}

661

662

663

664

665

666

667

668

669

670

671

672

673

674

675

676

677

678

679

680

681

682

683

684 
685 Table 2. Parameter settings for PBR cultivation

\begin{tabular}{ll}
\hline Parameter & Setting \\
\hline Temperature & $37^{\circ} \mathrm{C}$ \\
$\mathrm{pH}$ & 7.0 \\
Light intensity & $400 \mu \mathrm{mol} \mathrm{m}^{-2} \mathrm{~s}^{-1}$ \\
Air flow rate & $160 \mathrm{ml} \mathrm{min}^{-1}$ \\
$\mathrm{CO}_{2}$ flow rate & $40 \mathrm{ml} \mathrm{min}^{-1}$ \\
\hline
\end{tabular}

686

687

688

689

690

691

692

693

694

695

696

697

698

699

700

701

702

703

704

705

706

707

708 
709 Table 3. Specifications and market prices of desirable products.

\begin{tabular}{lrrr}
\hline \multicolumn{1}{c}{ Product } & \multicolumn{1}{c}{ Specification } & \multicolumn{1}{c}{ Price } & \multicolumn{1}{c}{ Reference } \\
\hline FAME & B100 biodiesel & $734 € \mathrm{t}^{-1}$ & Keysun Bio-Tech Co.Ltd \\
Amino acids & AA content: $54.4 \%$ & $426 € \mathrm{t}^{-1}$ & Seek Bio-Technology Co.Ltd \\
Lutein & $80 \%$ & $284 € \mathrm{~kg}^{-1}$ & Xi'an Lyphar Biotech Co.Ltd \\
Chlorophyllin & $95 \%$ & $165 € \mathrm{~kg}^{-1}$ & Xi'an Lyphar Biotech Co.Ltd \\
$\beta$-carotene & $95 \%$ & $411 € \mathrm{~kg}^{-1}$ & Xi'an Lyphar Biotech Co.Ltd \\
\hline
\end{tabular}

710

711

712

713

714

715

716

717

718

719

720

721

722

723

724

725

726

727

728

729

730

731

732

733

734

735 
736 Table 4. Comparison of experimental conditions and growth performance of $C$. 737 sorokiniana in flat panel $\mathrm{PBR}$. $\mathrm{PFD}=$ photon flux density, $\mathrm{D}=$ dilution rate, $\mathrm{C}_{\mathrm{X}}=$ biomass 738 concentration and $\mathrm{P}_{\mathrm{b}}=$ biomass productivity.

\begin{tabular}{llllll}
\hline Medium & PFD & $\mathrm{D}$ & $\mathrm{C}_{\mathrm{X}}$ & $\mathrm{P}_{\mathrm{b}}$ & Reference \\
\cline { 2 - 5 } & $\left(\mu \mathrm{mol} \mathrm{m}^{-2} \mathrm{~s}^{-1}\right)$ & $\left(\mathrm{d}^{-1}\right)$ & $\left(\mathrm{g} \mathrm{l}^{-1}\right)$ & $\left(\mathrm{g} \mathrm{l}^{-1} \mathrm{~d}^{-1}\right)$ & \\
\hline M8a & 2100 & 5.76 & 2.2 & 12.2 & \\
IC effluent & 2100 & 3.6 & 1.56 & 5.87 \\
IC effluent & 200 & 1.44 & 1.09 & 1,67 \\
KJ influent & 400 & 2.41 & 0.60 & 1.52
\end{tabular}

739

740

741

742

743

744

745

746

747

748

749

750

751

752

753

754

755

756

757

758

759 
761 Table 5. Comparison of media used for continuous cultivation of C. sorokiniana in flat 762 panel PBR.

\begin{tabular}{lllll}
\hline Indicator & Unit & M8a & IC effluent & KJ influent \\
\hline $\mathrm{COD}$ & $\mathrm{mg} \mathrm{O}_{2} \mathrm{l}^{-1}$ & - & 590 & 386.9 \\
$\mathrm{~N}_{\text {tot }}$ & $\mathrm{mg} \mathrm{N}^{-1}$ & 1680 & 190 & 48.6 \\
$\mathrm{P}_{\text {tot }}$ & $\mathrm{mg} \mathrm{P} \mathrm{1}^{-1}$ & 641 & $11-12$ & 7.2 \\
$\mathrm{NH}_{4}-\mathrm{N}$ & $\mathrm{mg} \mathrm{N}^{-1}$ & - & - &
\end{tabular}

763

764

765

766

767

768

769

770

771

772

773

774

775

776

777

778

779

780

781

782

783

784

785

786 
788 Table 6. Productivities of desired bioproducts.

\begin{tabular}{lrr}
\hline Product & Yield $(\%, \mathrm{w} / \mathrm{w})$ & Productivity $\left(\mathrm{mg}^{-1} \mathrm{~d}^{-1}\right)$ \\
\hline Biomass & & 1524 \\
FAME & 6.24 & \\
Protein & 38.82 & \\
Lutein & 0.103 & 1.182 \\
Chlorophylls & 0.044 \\
$\beta$-carotene & & \\
\hline
\end{tabular}

789

790

791

792

793

794

795

796

797

798

799

800

801

802

803

804

805

806

807

808

809

810 
811

812 Table 7. Fatty acids profile of $C$. sorokiniana

\begin{tabular}{llr}
\hline & Type of fatty acid & Percentage \\
\hline Total FAs $(\% \mathrm{dw})$. & & 6.24 \\
& Palmitic acid $(\mathrm{C} 16: 0)$ & 20.22 \\
Fatty acid $(\%$ total & Palmitoleic acid (C16:1) & \\
FAs) & Oleic acid (C18:1) & \\
& Linolenic acid (C18:3)
\end{tabular}

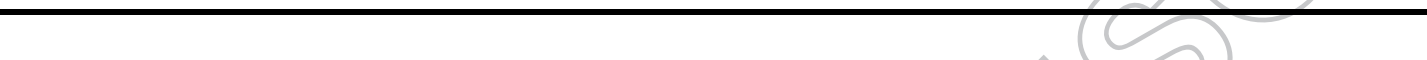


Table 8. Characterization of $C$. sorokiniana biomass in literatures.

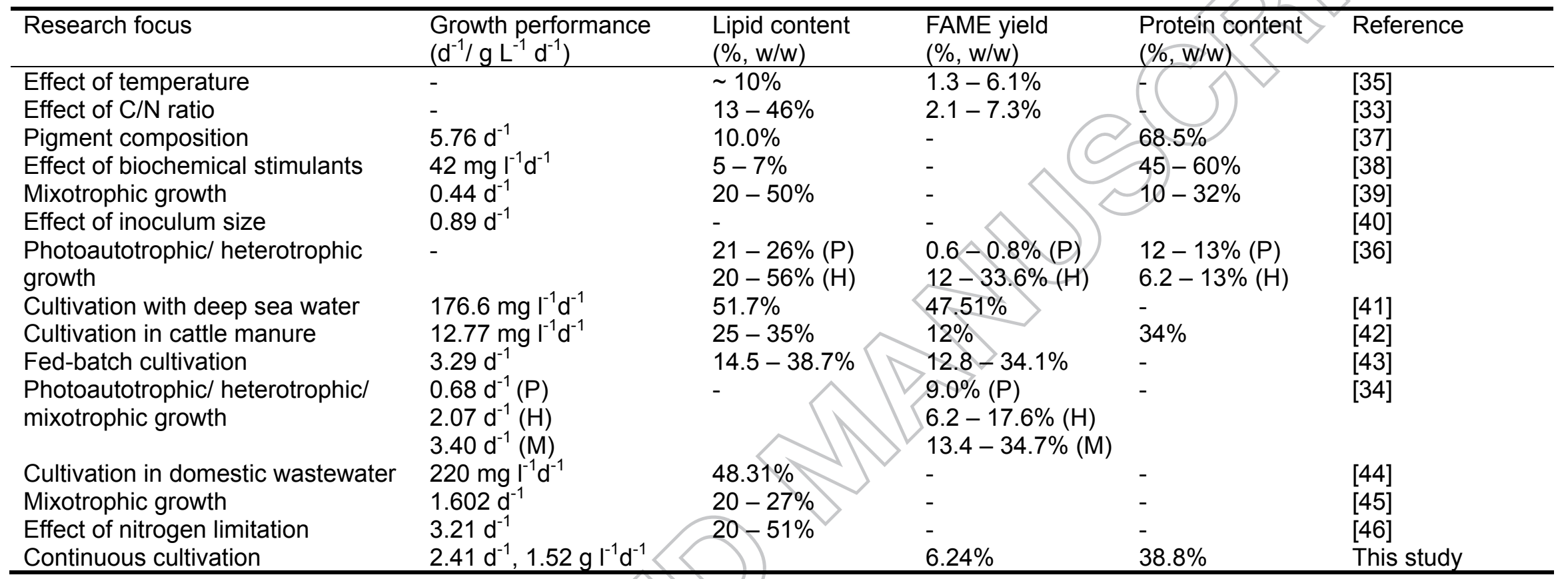


818 Table 9. Estimation of biomass value.

\begin{tabular}{|c|c|c|c|}
\hline Product & Yield & Productivity & Revenue \\
\hline Biomass & & $1.524 \mathrm{~g} \mathrm{l}^{-1} \mathrm{~d}^{-1}$ & \\
\hline FAME (B100) & $0.0624 \mathrm{~g} \mathrm{~g}^{-1}$ & $0.095 \mathrm{~g} \mathrm{l}^{-1} \mathrm{~d}^{-1}$ & $0.46 € \mathrm{~kg}^{-1}$ \\
\hline $\begin{array}{l}\text { Amino acid fertilizer } \\
(54.4 \%)\end{array}$ & $0.3882 \mathrm{~g} \mathrm{~g}^{-1}$ & $0.592 \mathrm{~g} \mathrm{l}^{-1} \mathrm{~d}^{-1}$ & $0.162 € \mathrm{~kg}^{-1}$ \\
\hline Lutein $(80 \%)$ & $1.03 \mathrm{mg} \mathrm{g}^{-1}$ & $1.565 \mathrm{mg} \mathrm{l}^{-1} \mathrm{~d}^{-1}$ & $0.292 € 1$ \\
\hline Chlorophyllin (95\%) & $11.81 \mathrm{mg} \mathrm{g}^{-1}$ & $18.014 \mathrm{mg} \mathrm{l}$ & $1.950 € \mathrm{~kg}^{-1}$ \\
\hline$\beta$-carotene $(95 \%)$ & $0.44 \mathrm{mg} \mathrm{g}^{-1}$ & $0.671 \mathrm{~m}$ & $0.181 € \mathrm{~kg}^{-1}$ \\
\hline Sum & & & $2.630 € \mathrm{~kg}^{-1}$ \\
\hline Wastewater treatment & Removal & Quantity & Revenue \\
\hline \multicolumn{4}{|l|}{ Wastewater } \\
\hline COD & $52.1 \%$ & $0.319 \mathrm{~kg} \mathrm{~kg}^{-1}$ & $0.042 € \mathrm{~kg}^{-1}$ \\
\hline Nitrogen & & $0.044 \mathrm{~kg} \mathrm{~kg}^{-1}$ & $0.356 € \mathrm{~kg}^{-1}$ \\
\hline Phosphorus & & $0.008 \mathrm{~kg} \mathrm{~kg}^{-1}$ & $0.242 € \mathrm{~kg}^{-1}$ \\
\hline Sum & & & $0.640 € \mathrm{~kg}^{-1}$ \\
\hline Total revenue & & & $3.271 € \mathrm{~kg}^{-1}$ \\
\hline
\end{tabular}

819

820

821

822

823

824

825

826

827

828 
830

831 Figure 1. Specific growth rates in different dilutions of wastewater (Green: $C$.

832 sorokiniana, Red: S. obliquus; striped columns correspond to the $1^{\text {st }}$ generation, full

833 columns to the $2^{\text {nd }}$ generation).

834

835 Figure 2. Growth curves: (a) C. sorokiniana, first generation, (b) C. sorokiniana, second 836 generation, (c) S. obliquus, first generation, (d) S. obliquus, second generation 837 (wastewater concentration: square-100\%, diamond-75\%, triangle-50\%, circle- $25 \%$ ) 838

839 Figure 3. Effect of dilution rates on cell concentration and volumetric productivity. 840

841 Figure 4. Bioflocculation in PBR (left), microscopic image of bioflocs (right).

842

843 Figure 5. Effect of dilution rates on nutrient removal efficiencies.

844

845 Figure 6. Scenarios for potential cost reduction.

846 


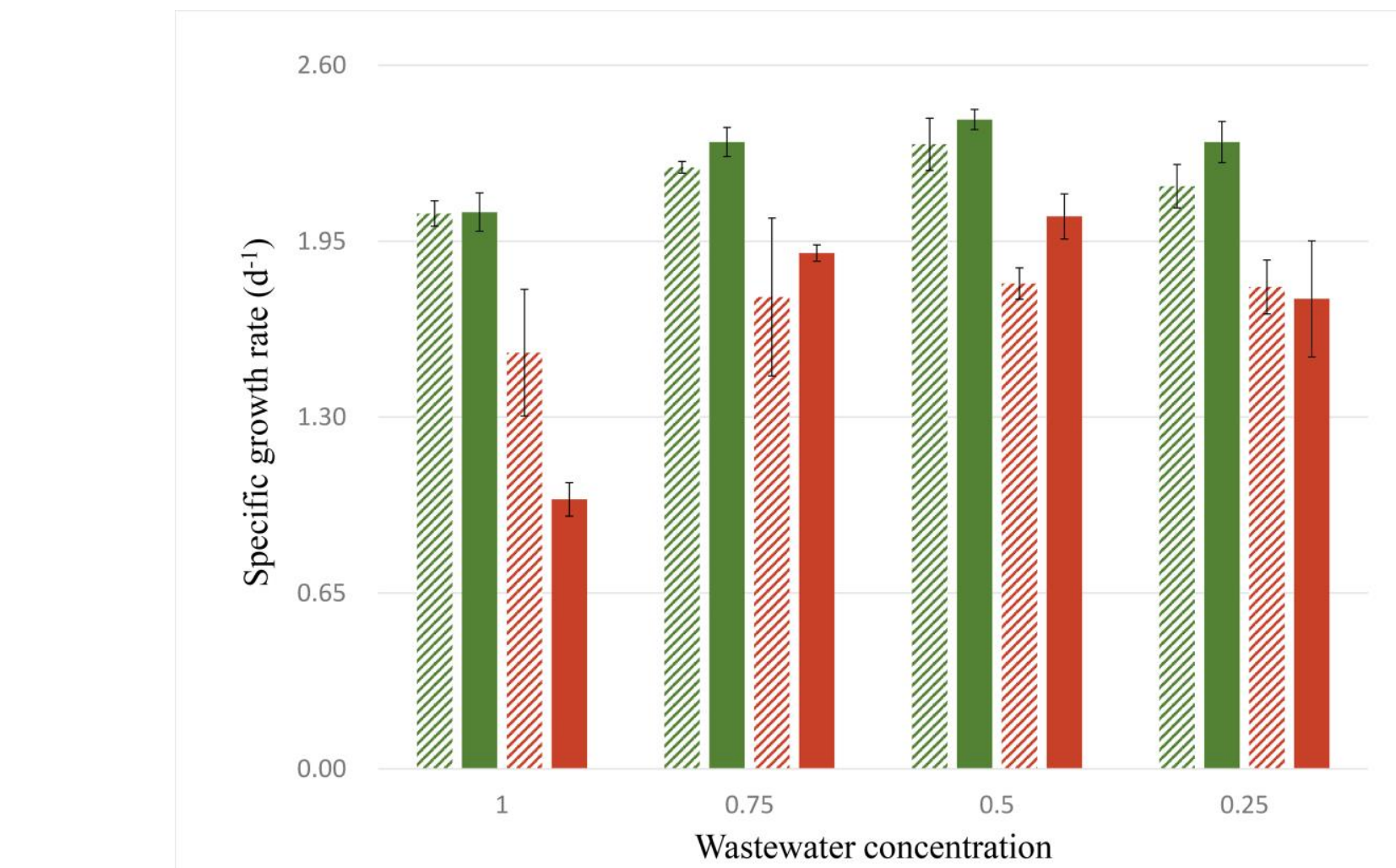

847 


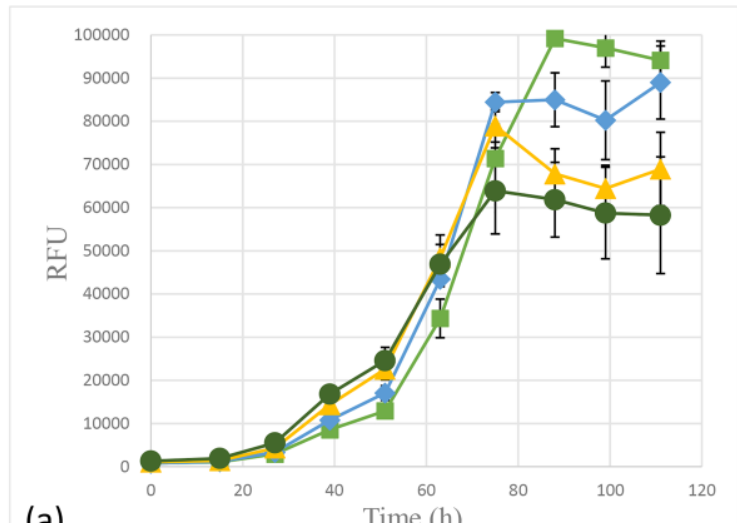

(a)

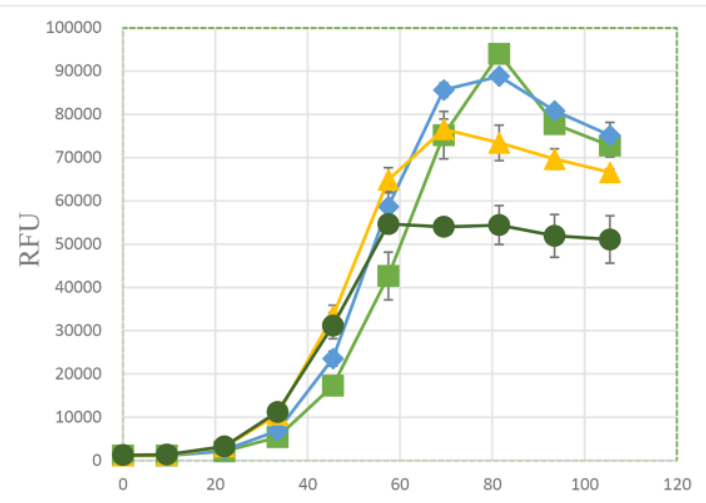

(b)

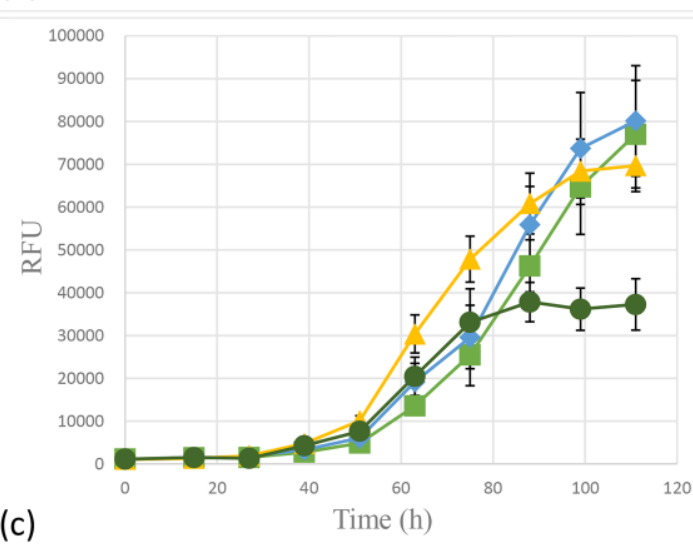

(c)

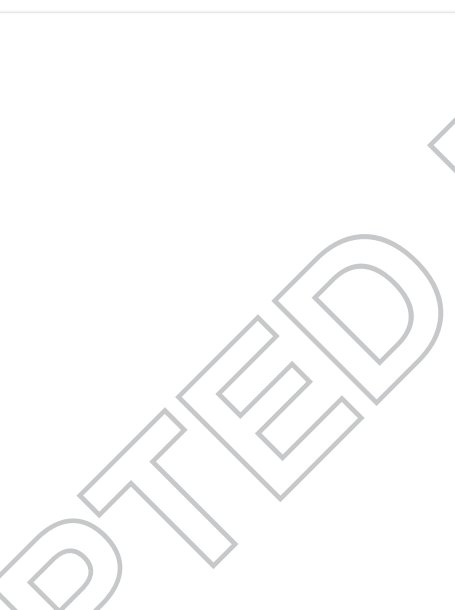

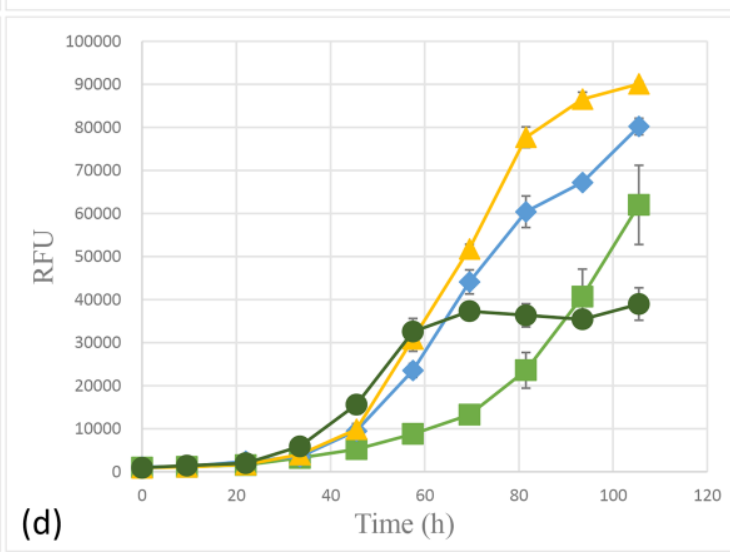

(d) 


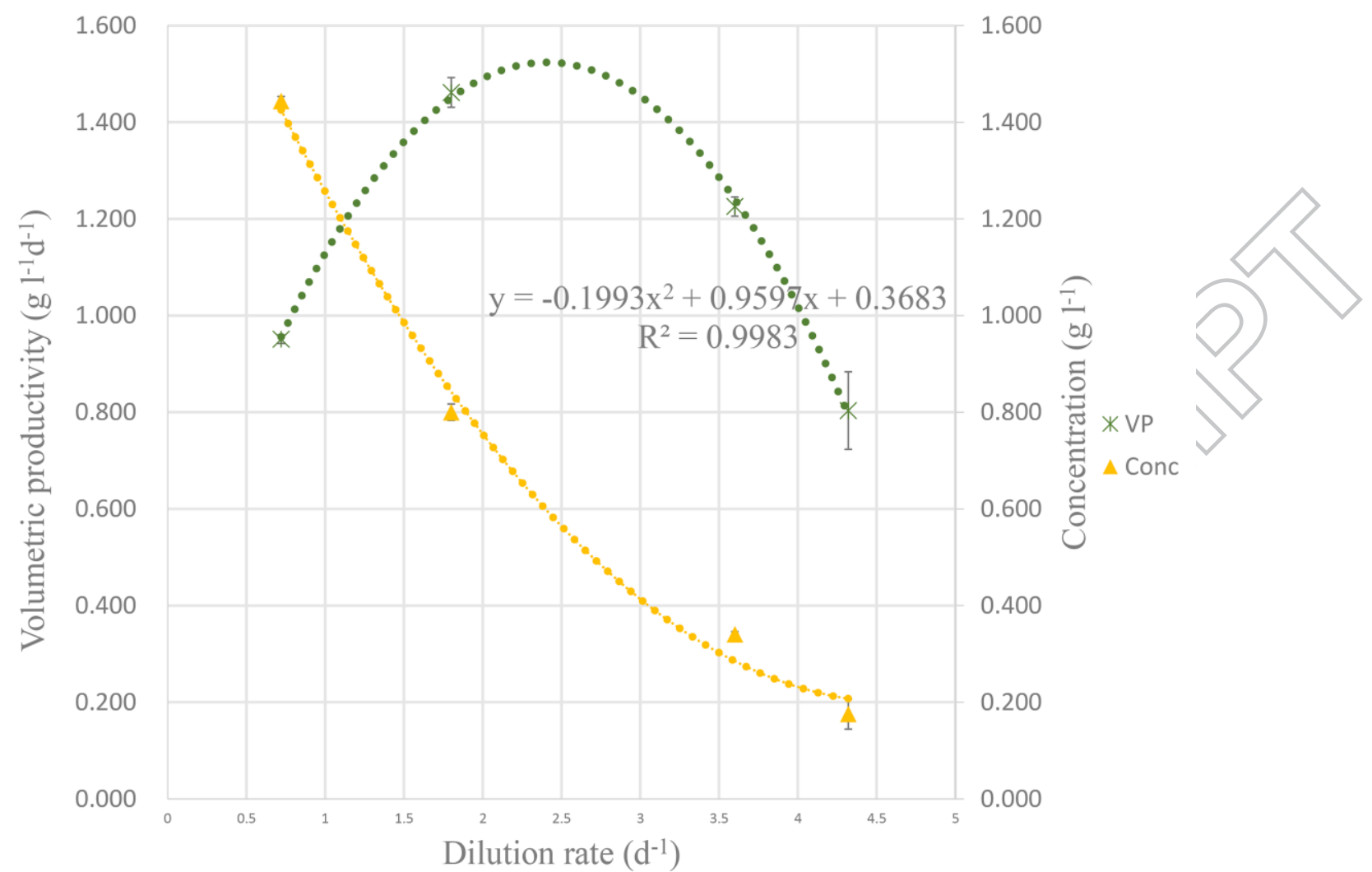

849

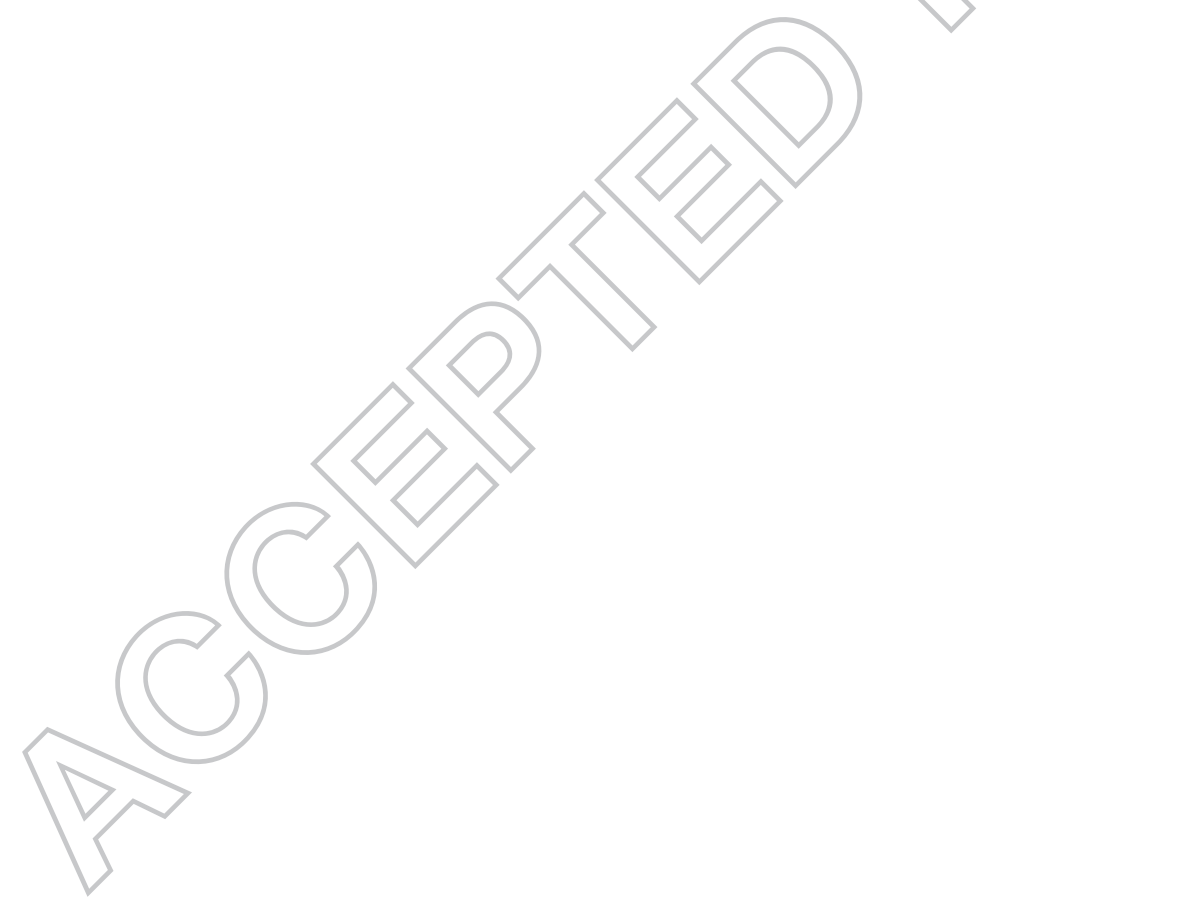




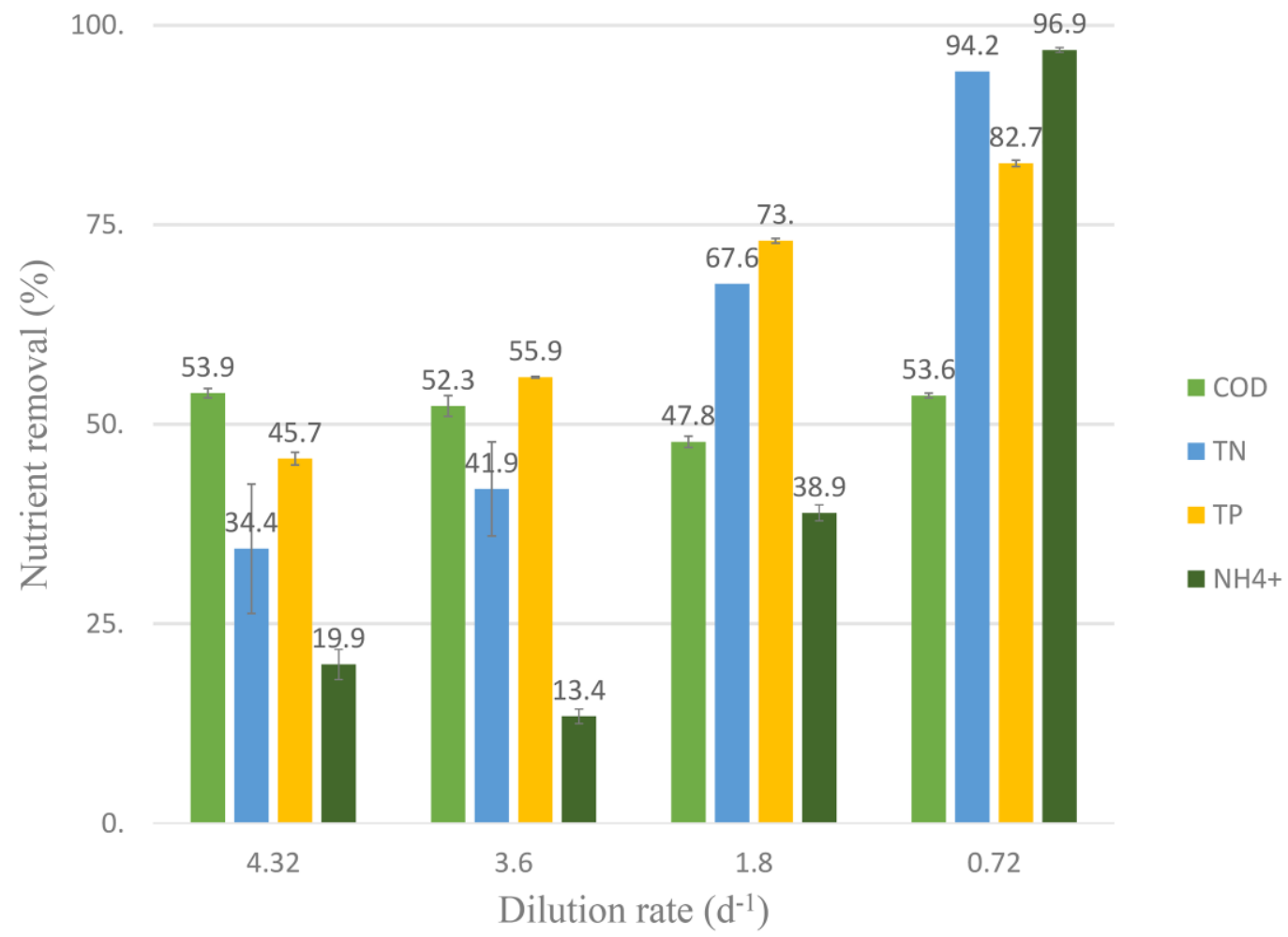

850 


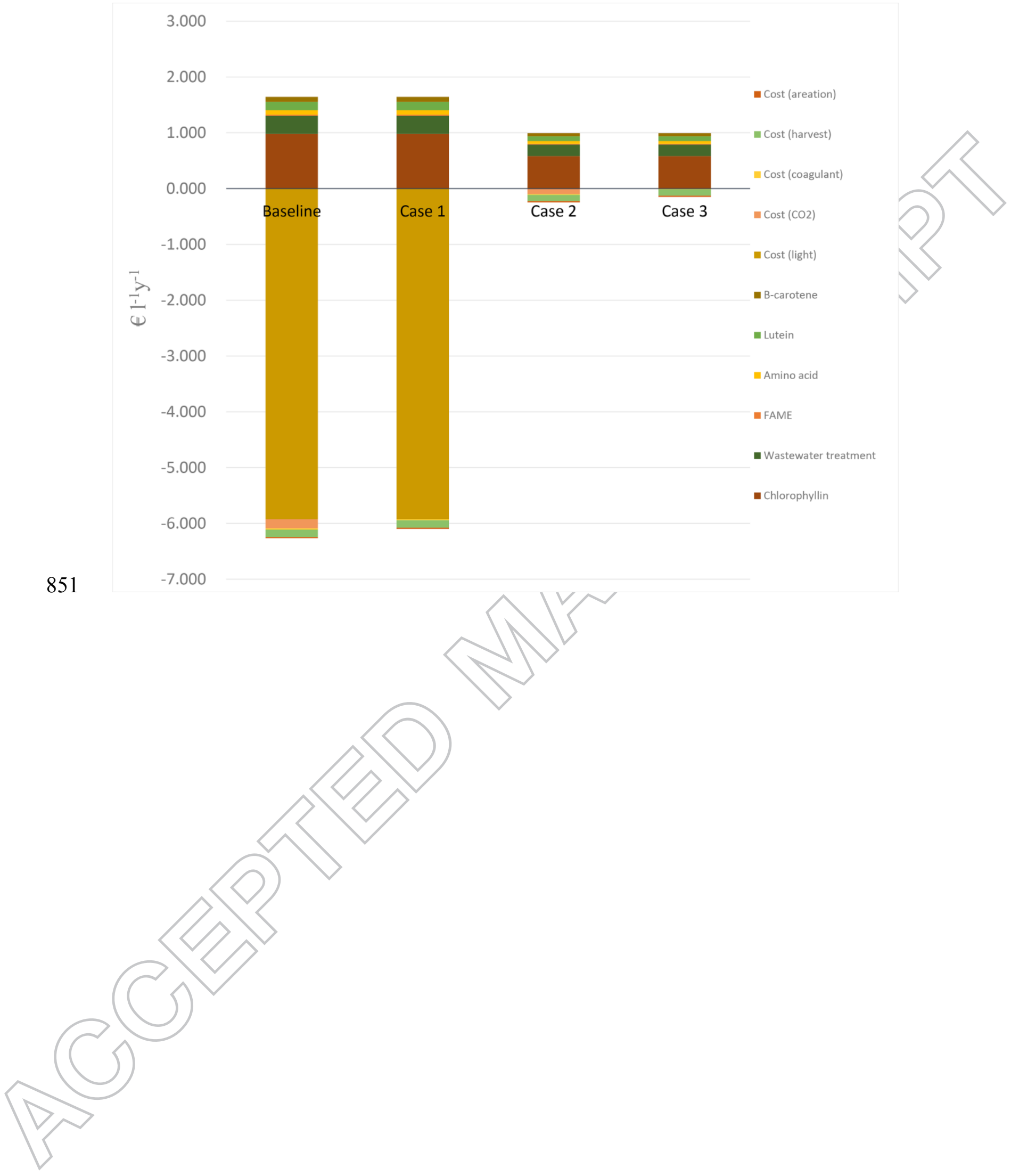




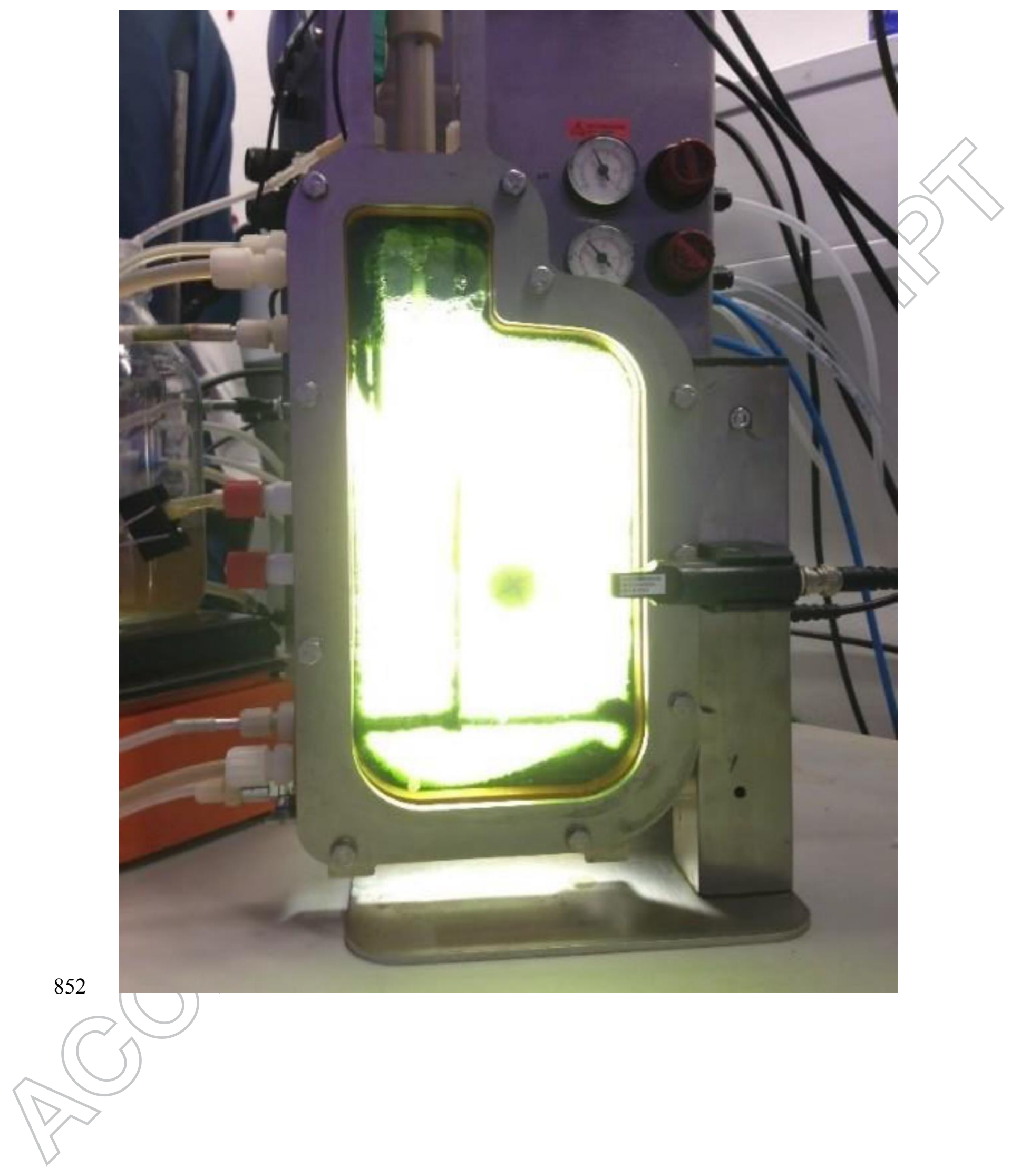




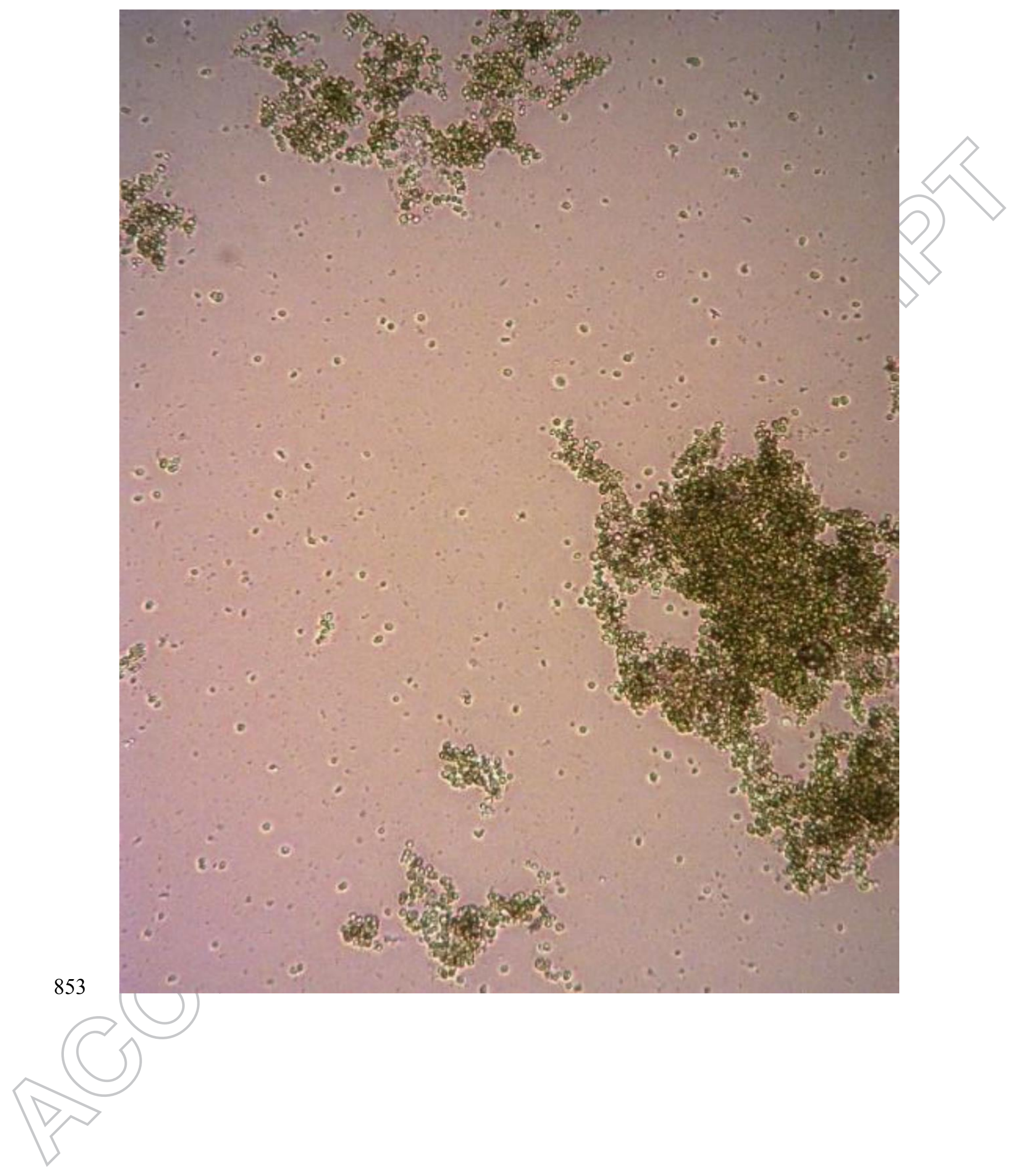

